\title{
Effects of Mixing Temperature on the Mechanical Properties of Hot Mix Asphalt
}

\author{
Gül BALIK ${ }^{1}$ \\ Mehmet YILMAZ ${ }^{2}$ \\ Baha Vural KÖK ${ }^{3}$ \\ Taner ALATAŞ ${ }^{4}$
}

\begin{abstract}
In this study, the effects of mixing temperature on the performance of hot mix asphalt (HMA) were investigated. 5\% Styrene-butadiene-styrene (SBS) and 18\% America Gilsonite were used as binder modifiers. HMA samples were prepared at the mixing temperatures $10^{\circ} \mathrm{C}$, $15^{\circ} \mathrm{C}$, and $20^{\circ} \mathrm{C}$ lower temperatures than the mixing temperature. Marshall Stability and flow, resistance to moisture-induced damage and indirect tensile fatigue tests were conducted on the hot mix asphalt samples. As a result of the experimental study, it was observed that use of additives increased the performance of the HMAs. In addition, it was seen that, in general, the stability, Marshall quotient, indirect tensile strength and fatigue life of the mixtures decreased and the flow values increased with decreasing mixing temperature.
\end{abstract}

Keywords: Mixing temperature, hot mix asphalt, styrene-butadiene-styrene, gilsonite, superpave, performance.

\section{INTRODUCTION}

Hot mix asphalts (HMAs), which can be used in the base and surface layers of flexible pavements, are comprised of bituminous binder and aggregate. Due to the rheological properties of bituminous binders, they act as an elastic solid at high vehicle speeds and low temperatures while demonstrating viscous liquid properties at low vehicle speeds and hightemperatures $[1,2]$. Because these properties of bituminous binders are reflected in the

\section{Note:}

- This paper has been received on March 14, 2018 and accepted for publication by the Editorial Board on November 12, 2018.

- Discussions on this paper will be accepted by September 30, 2019.

- https://dx.doi.org/10.18400/tekderg.405948

1 Firat University, Department of Civil Engineering, Elazığ, Turkey - guldoner23@hotmail.com https://orcid.org/0000-0001-7614-9862

2 Frrat University, Department of Civil Engineering, Elazığ, Turkey - mehmetyilmaz@firat.edu.tr https://orcid.org/0000-0002-2761-2598

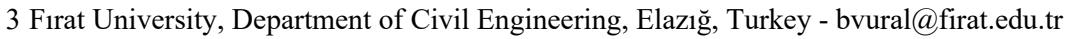
https://orcid.org/0000-0002-7496-6006

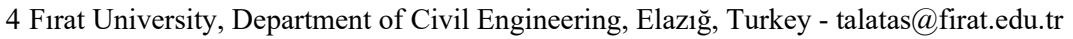
https://orcid.org/0000-0002-2762-0440 
mixture, the rheological behaviors of bituminous binders are significant regarding pavement performance.

Various materials are added to the bituminous binders for different reasons and a modified kind of bitumen is obtained. The main reasons for bitumen modification are increases in the price of crude oil, consequently preference of thinner pavements due to high costs, significant increases in traffic loads, thereby shortening the service life of pavements, inability of classical binders to provide the desired level of performance, the inclination toward use of industrial wastes, the need for an increase in strength to prevent formation of deformations and high costs of maintenance [3].

Modifiers are substances, which can change the chemical, physical and/or mechanical properties of pure binders when added to pure binders. For a long time, researchers and chemists have conducted studies on modified bitumen. These studies were focused on the industrial utilization of graphite, specific fillers, mineral fibers, plastomers, elastomers and rubbers for bitumen modification [4-7]. The most commonly used modifiers are polymers [8]. Polymers are macromolecules, in which the same groups of atoms are repeated for several times [3]. Each repeated group can consist of one or several different molecules (monomer). Styrene-butadiene-styrene (SBS) block copolymers of the elastomer class increase the elasticity of bitumen and are the most suitable and commonly used polymer used in bitumen modification $[9,10]$. SBS copolymers provide their durability and elasticity due to the physical structure and cross binding of their molecules, which form a three-dimensional network. Polystyrene end-blocks increase the strength while polybutadiene elastic matrix blocks provide the extraordinary viscosity of the material [11]. When SBS is mixed with bitumen, the elastomeric phases of SBS copolymer absorb the oil fractions in bitumen and can swell about nine times of the initial volume [12]. In a suitable SBS concentration, a polymer phase is constantly formed during polymer modified bitumen (PMB) and the properties of pure binder change significantly.

Gilsonite, which is a member of the hydrocarbon class in bitumen additives and a natural bitumen source, contains hydrocarbons, which are $99 \%$ pure, and possesses a bitumen content, which varies between 57-70\% $[13,14]$. Because Gilsonite is a substance that contains resin, it is used in various industrial fields [15]. Generally, Gilsonite is a by-product natural crude oil, and it splits from the rocks undergrounds and rises to the ground surface via the cracks in the surface layers. If the natural bitumen reaches ground surface, a bitumen source is formed. Otherwise, it stays underground, and if it stays isolated from the ground surface, it slowly hardens, becoming oxidized and eventually, it forms a solid and hard substance, which is the mineral bitumen. Gilsonite is a black and fragile substance and it can be turned into powder easily [16]. When Gilsonite is mixed with bitumen, its consistency increases. In addition to being mixed into bitumen, Gilsonite can also be added to the mixture [17]. As a result of the studies conducted on America and Iran Gilsonite, it was concluded that these additives improved the elasticity and high-temperature properties of bituminous binders [16, $18,19,20]$. In another study, it was concluded that although America Gilsonite use increased the high-temperature behavior of bituminous binder, the practice also increased the crack formation possibility at low temperatures [21]. When aggregates are covered with Gilsonite modified bitumen, a notable interface is formed between the aggregate and the bitumen, thus, crack formation can be prevented in pavements [22]. It was also reported that Colombia Gilsonite, just as the Gilsonite from other countries, improved the high-temperature 
properties of HMAs [23]. In previous studies, it was reported that Iran Gilsonite was more effective in terms of resistance to fatigue and permanent deformations as compared to America Gilsonite [24,25]. Gilsonite, due to its positive effects on bituminous binders and mixtures, especially on high-temperature resistance, is a considerable alternative material to polymers [26].

In order to obtain the expected performance of HMAs, they should be produced with suitable materials, designed in a suitable way as well as being produced under suitable conditions and in a suitable way. One of the parameters that affect the performance of HMAs is the mixing temperature. In general, a temperature range corresponding to $170 \pm 20 \mathrm{cP}$ is chosen for mixing and the range corresponding to $280 \pm 30 \mathrm{cP}$ is chosen for compaction [27]. These values are generally determined by rotational viscosimeter test. Although the mixing temperature of aggregate and bitumen is determined during the design process, the required temperature may not be achieved due to conditions, which occasionally result from personnel or equipment insufficciency.

According to data from 2015 in Turkey, the General Directorate of highways, special provincial administrations, municipalities and private firms possess 857 asphalts plants [28]. Although some of these plants go through regular maintenances and checks, some of them have over run their regular maintenance periods. Especially in several cities, it is believed that one of the reasons early deteriorations of the hot mix asphalt urban and village roads result from manufacturing defects.

In this study, the effects of mixing temperature on the performance of HMAs, which were prepared with modified binders, which contained commonly-used additives (SBS and Gilsonite). For this purpose, 5\% styrene-butadiene-styrene (SBS) and 18\% America Gilsonite $(\mathrm{G})$ were used in the preparation of the modified bitumen. The mixing temperature was determined for pure bitumen and the modified bitumen. HMA samples were prepared at the determined mixing temperature and $10^{\circ} \mathrm{C}, 15^{\circ} \mathrm{C}$ and $20^{\circ} \mathrm{C}$ lower temperatures than mixing temperature. The prepared HMA samples were subjected to tests of resistance to moisture-induced damage, Marshall Stability and flow and indirect tensile fatigue. Thus, the effects of mixing temperature on the performance of HMAs were investigated.

\section{MATERIALS AND METHODS}

In this study, the effects of mixing temperature on the performances of HMAs prepared with pure bitumen and styrene-butadiene-styrene (SBS, obtained from the Shell Chemicals Company) and America Gilsonite (G, obtained from the American Gilsonite Company) modified bitumen. For preparing the modified binders, the pure bitumen and additives were mixed for 60 minutes at a temperature of $180^{\circ} \mathrm{C}$ in a mixer with a rotation rate of $1,000 \mathrm{rpm}$. As for the pure bitumen, PG 52-28 grade binder, which was obtained from the TÜPRAŞ refinery in Turkey, was used. The city with the warmest climate in Turkey, Şanliurfa, was chosen as the city for investigation and the target performance level was chosen as PG 76-16 according to the temperature data. In order to achieve this performance level in previous studies, it was reported that it was necessary to use 5\% SBS and $18 \%$ Gilsonite [29]. The results of the Superpave tests conducted on the binders were presented in Table 1. 
Table 1 - DSR and BBR test results of neat and modified binders [29].

\begin{tabular}{|c|c|c|c|c|}
\hline \multirow{12}{*}{ 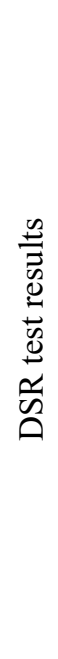 } & \multirow{2}{*}{ Temp. $\left({ }^{\circ} \mathrm{C}\right)$} & \multicolumn{3}{|c|}{$\mathrm{G}^{*} / \sin \delta(\mathrm{kPa})$ (specification limit min. $\left.1 \mathrm{kPa}\right)$} \\
\hline & & PG 52-28 & $5 \% \mathrm{SBS}$ & $18 \%$ Gilsonite \\
\hline & 52 & 2.021 & - & - \\
\hline & 76 & - & 1.367 & 1.504 \\
\hline & & \multicolumn{3}{|c|}{$\mathrm{G}^{*} / \sin \delta(\mathrm{kPa}) \mathrm{RTFOT}$ residue (specification limit min. $\left.2.2 \mathrm{kPa}\right)$} \\
\hline & 52 & 8.782 & - & - \\
\hline & 76 & - & 4.673 & 8.678 \\
\hline & & \multicolumn{3}{|c|}{$\mathrm{G}^{*} . \sin \delta(\mathrm{kPa})$ PAV residue (specification limit max. $5000 \mathrm{kPa}$ ) } \\
\hline & 16 & 2023 & - & - \\
\hline & 25 & - & 739 & 4213 \\
\hline & 28 & - & 556 & 3186 \\
\hline & 31 & - & 398 & 2345 \\
\hline \multirow{11}{*}{ 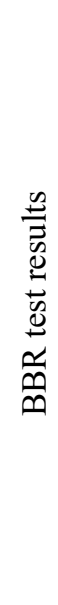 } & & \multicolumn{3}{|c|}{ m-value (specification limit min. 0.300 ) } \\
\hline & 1еmp.( C) & PG 52-28 & $5 \% \mathrm{SBS}$ & $18 \%$ Gilsonite \\
\hline & -6 & & 0.330 & 0.333 \\
\hline & -12 & - & 0.291 & 0.294 \\
\hline & -18 & 0.562 & & \\
\hline & -24 & 0.451 & & \\
\hline & & \multicolumn{3}{|c|}{ Creep stiffness (Mpa) (specification limit max. $300 \mathrm{MPa}$ ) } \\
\hline & -6 & - & 43.2918 & 151.0398 \\
\hline & -12 & & 76.790 & 283.9786 \\
\hline & -18 & 165.7 & & \\
\hline & -24 & 325.4 & & \\
\hline \multicolumn{2}{|c|}{$\begin{array}{l}\text { Performance grades } \\
\text { (PG) }\end{array}$} & $52-28$ & $76-16$ & $76-16$ \\
\hline
\end{tabular}

Bituminous binders should have viscosity values of $170 \pm 20 \mathrm{cP}$ during mixing with the aggregate and $280 \pm 30 \mathrm{cP}$ during laying out [30]. For this test, spindle No. 27 was chosen and the spindle speed was set to $20 \mathrm{rpm}$. Rotational viscometer tests were applied to pure and modified binders under two different temperatures $\left(135\right.$ and $\left.165^{\circ} \mathrm{C}\right)$. Viscosity-temperature graphs plotted with the obtained results were used to determine aggregate mixing temperatures and compaction temperatures. Findings obtained in the rotational viscometer test were presented in Table 2.

Similar to binder design, mix design was also conducted with the Superpave method as well. For this purpose, dense graded asphalt mixtures with crushed-stone aggregate suitable for 
Superpave gradation and with a maximum size of $19 \mathrm{~mm}$ were prepared. The limestone type

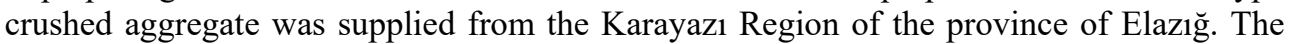
properties of the aggregate were presented in Table 3. Additionally, the adopted gradation was presented in Figure 1.

Table 2 - Rotational viscosity test results [29].

\begin{tabular}{|c|c|c|c|c|}
\hline Properties & Standard & PG 52-28 & $5 \% \mathrm{SBS}$ & $18 \%$ Gilsonite \\
\hline Viscosity $\left(\mathrm{cP}, 135^{\circ} \mathrm{C}\right)$ & \multirow{2}{*}{ ASTM D4402 } & 250.0 & 1513 & 1113 \\
\hline Viscosity $\left(\mathrm{cP}, 165^{\circ} \mathrm{C}\right)$ & & 100 & 487.5 & 287.5 \\
\hline $\begin{array}{l}\text { Modification index } \\
\left(\eta_{\text {modifiye }} / \eta_{\text {saf }}, 135^{\circ} \mathrm{C}\right)\end{array}$ & - & 1.00 & 6.05 & 4.45 \\
\hline $\begin{array}{l}\text { Modification index } \\
\left(\eta_{\text {modifiye }} / \eta_{\text {saf }}, 165^{\circ} \mathrm{C}\right)\end{array}$ & - & 1.00 & 4.88 & 2.88 \\
\hline $\begin{array}{l}\text { Mixing temperature } \\
\text { range }\left({ }^{\circ} \mathrm{C}\right)\end{array}$ & - & $146.2-153.9$ & 190.1-194.9 & 174.6-179.9 \\
\hline $\begin{array}{l}\text { Compaction temperature } \\
\text { range }\left({ }^{\circ} \mathrm{C}\right)\end{array}$ & - & $130.5-137.4$ & $175.8-181.5$ & $163.8-168.5$ \\
\hline
\end{tabular}

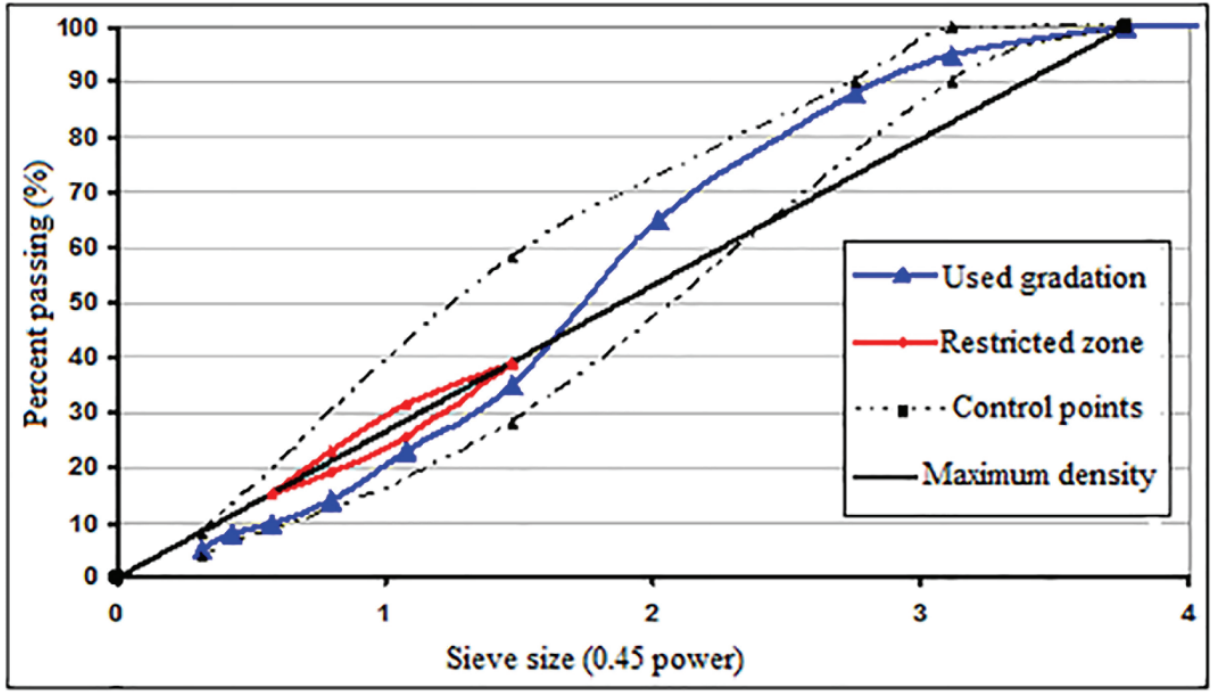

Figure 1 - Combined aggregate gradation.

As shown in Table 1, high-temperature resistance of binders was increased and low temperature resistance was decreased with additive use. The province of Şanlıurfa was 
selected as the application area where the high temperature resistance of the binders is more important. Therefore, negativity at low temperature is not taken into account. When the rotational viscosity values given in Table 2 were examined, it was determined that the consistency of the binders increased with the use of additives. Due to the increase in viscosity, the mixtures prepared with modified bitumen required higher mixing and compaction temperatures.

Table 3 - Physical properties of the aggregate [29].

\begin{tabular}{lccccc}
\hline \multicolumn{1}{c}{ Properties } & Standard & $\begin{array}{c}\text { Specificati } \\
\text { on limits }\end{array}$ & Coarse & Fine & Filler \\
\hline $\begin{array}{l}\text { Abrasion loss (\%) } \\
\text { (Los Angeles) }\end{array}$ & ASTM D 131 & Max 30 & 29.2 & - & - \\
$\begin{array}{l}\text { Abrasion loss (\%) } \\
\text { (Micro deval) }\end{array}$ & ASTM D 6928 & Max 15 & 17.4 & - & - \\
$\begin{array}{l}\text { Frost action }(\%) \\
\left(\text { with Na } \mathrm{SO}_{4}\right)\end{array}$ & ASTM C 88 & Max 18 & 16.7 & - & - \\
$\begin{array}{l}\text { Methylene blue }\left(\mathrm{gr} / \mathrm{kg}^{2}\right) \\
\text { Specific gravity }\left(\mathrm{g} / \mathrm{cm}^{3}\right)\end{array}$ & ASTM C 837 & Max 1.5 & 0.5 & & \\
$\begin{array}{l}\text { Specific gravity }\left(\mathrm{g} / \mathrm{cm}^{3}\right) \\
\text { Specific gravity }\left(\mathrm{g} / \mathrm{cm}^{3}\right)\end{array}$ & ASTM C128 & & 2.626 & - & - \\
\hline
\end{tabular}

Superpave Gyratory Compactor (SGC) which imparts a constant vertical pressure of $600 \mathrm{kPa}$ to the sample was used for sample compaction. SGC gyrates the sample with an eccentricity of $1.25^{\circ}$ from the vertical axis. Design number of gyration was chosen as 100 . In the study, the bitumen contents, which provide $4 \%$ air voids at determined mixing and compaction temperature, were obtained. In order to evaluate the effect of the decrease in the mixing temperature on the performance of the HMAs, the same bitumen contents were used in the mixtures prepared at different temperatures.

At the determined mixture and compaction temperatures, $4.61 \%$ bitumen was used in mixtures prepared with pure binders, $5.05 \%$ bitumen in mixtures prepared with $5 \%$ SBS modified bitumen, $4.91 \%$ bitumen in mixtures prepared with $18 \%$ Gilsonite modified bitumen [29]. In the contents of bitumen and 4 different mixing temperatures (at mixing temperature and $10^{\circ} \mathrm{C}, 15^{\circ} \mathrm{C}$ and $20^{\circ} \mathrm{C}$ lower than this temperature) mentioned in the study, the mixture samples were prepared. The mixing temperatures used in the study were presented in Table 4.

Marshall stability and flow (EN 12697-34), moisture-induced damage (AASHTO T 283) and indirect tensile fatigue (BS DD ABF) tests were performed on the mixtures prepared at different mixing temperatures. Thus, the effects of the change in mixing temperature on the fatigue, moisture-induced damage and stability of HMAs were evaluated. 
Table 4 - Mixing temperatures of mixtures.

\begin{tabular}{lcccc}
\hline & $\begin{array}{c}\text { Mixing temperature } \\
\left({ }^{\circ} \mathrm{C}\right)\end{array}$ & $\begin{array}{c}\text { Mixing } \\
\text { temperature } \\
-10\left({ }^{\circ} \mathrm{C}\right)\end{array}$ & $\begin{array}{c}\text { Mixing } \\
\text { temperature } \\
-15\left({ }^{\circ} \mathrm{C}\right)\end{array}$ & $\begin{array}{c}\text { Mixing } \\
\text { temperature } \\
-20\left({ }^{\circ} \mathrm{C}\right)\end{array}$ \\
\hline Abbreviations & $1 \mathrm{MT}$ & $\mathrm{MT}-10$ & $\mathrm{MT}-15$ & $\mathrm{MT}-20$ \\
PG 52-28 & 150 & 140 & 135 & 130 \\
$5 \%$ SBS & 193 & 183 & 178 & 172 \\
$18 \%$ Gilsonite & 177 & 167 & 162 & 157 \\
\hline
\end{tabular}

\section{RESULTS AND DISCUSSION}

In the study, Marshall Stability and flow test, resistance to moisture-induced damage and indirect tensile fatigue tests were conducted on the HMA samples prepared at 4 different mixing temperatures.

\subsection{Marshall Stability and Flow Test Results}

In this study, a total of 36 samples were prepared using 3 different binders (pure bitumen, $5 \%$ SBS and $18 \%$ Gilsonite modified bitumen) at 4 different mixing temperatures (MT, MT10, MT-15 and MT-20) and these samples were subjected to Marshall stability and flow test according to EN 12697-34 standard. The prepared samples were kept in water, at $60^{\circ} \mathrm{C}$, for 40 minutes and were cracked at $50.8 \mathrm{~mm} / \mathrm{min}$ load speed. The final values were determined by multiplying the automatically determined stability values by the correction values, which depended on the height of the samples. The Marshall Stability values of the mixtures were presented in Figure 2 while the flow values were presented in Figure 3 and the Marshall Quotient (MQ) values were presented in Figure 4.

As it can be seen in Figure 2, the stability rates of mixtures prepared with $18 \%$ Gilsonite and $5 \%$ SBS modified bitumen were higher compared to the mixtures prepared with pure binder. It was determined that an irregular change occurred in the stability values of mixtures prepared with the pure binder with decreased mixing temperature. It was also observed that the differences between the values of the mixtures prepared with pure binder, the difference between the highest and lowest stability values were only 3.4\%. Furthermore, it was observed that the values were close to each other in mixtures prepared with $5 \% \mathrm{SBS}$, the difference between the highest and lowest stability values were only $1.2 \%$ in mixtures prepared with $5 \%$ SBS modified bitumen. It was seen that the stability values reduced the most in mixtures prepared with $18 \%$ America Gilsonite modified binders by changing the mixing temperature. The highest stability values were obtained from the mixtures prepared at the mixing temperature and $10^{\circ} \mathrm{C}$ lower than the mixing temperature while the lowest stability values were obtained from the mixtures prepared at $20^{\circ} \mathrm{C}$ lower than the mixing temperature. It was observed that the difference between the highest and lowest stability values of the mixtures prepared with $18 \%$ Gilsonite modified bitumen were $36.6 \%$. 
HMA wearing courses should have a minimum $900 \mathrm{~kg}$ Marshall stability value according to Technical Specifications of the Turkish General Directorate of Highways (TCK). As seen in Figure 2, all mixtures met the specification's requirements.

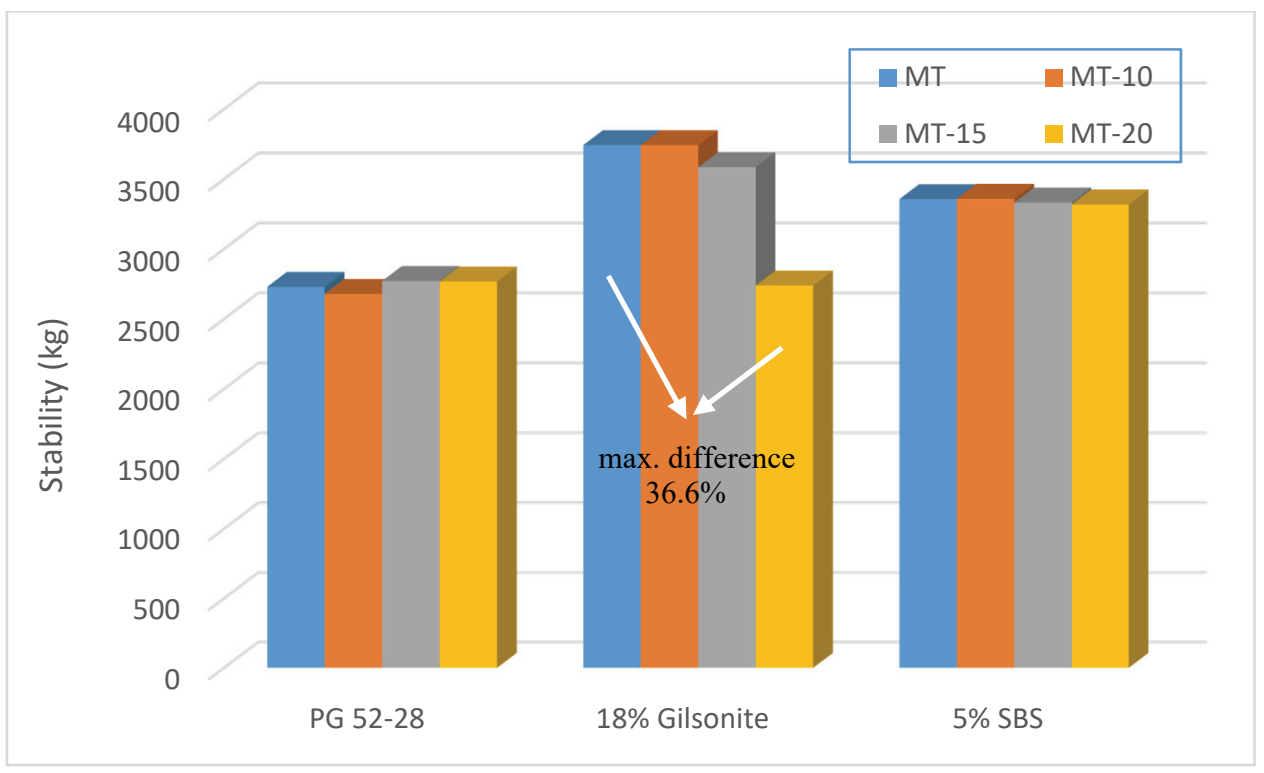

Figure 2 - Marshall stability values of mixtures.

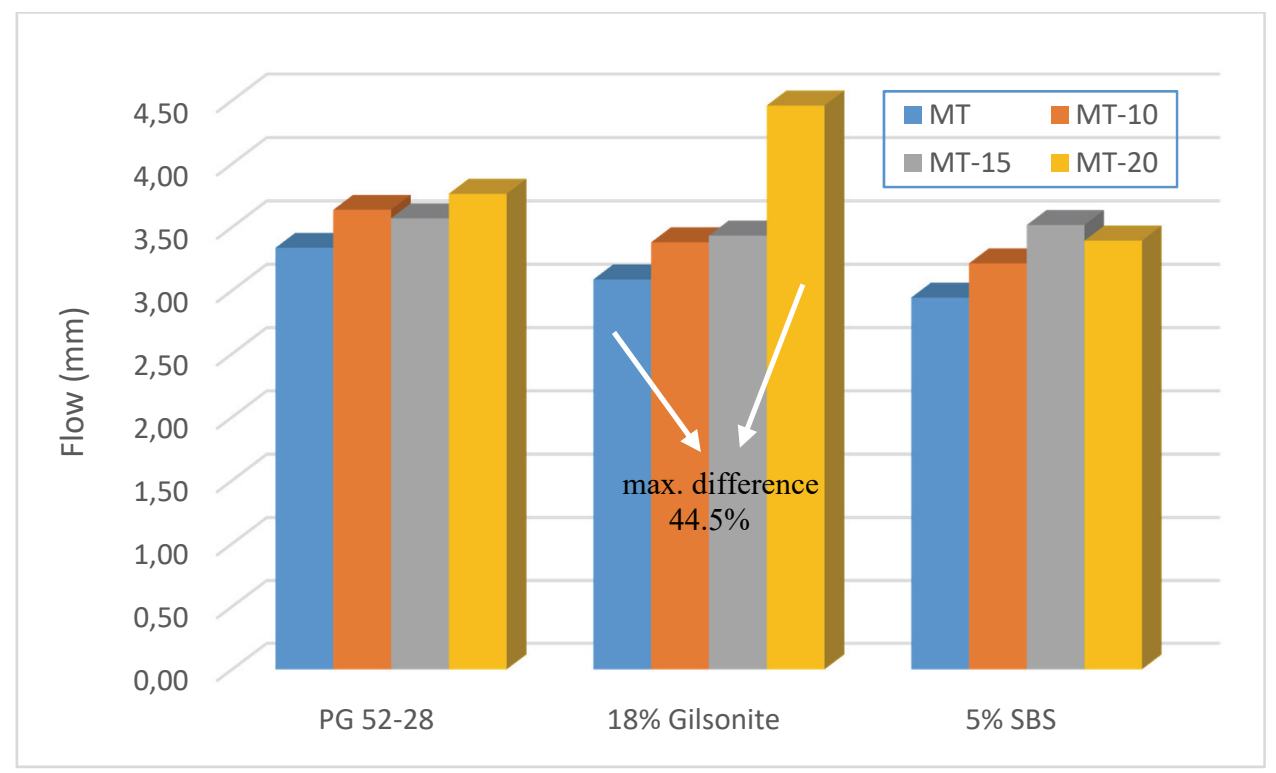

Figure 3 - Flow values of mixtures. 
In the examination of the flow results in Figure 3, it was determined that the flow values were generally increased with decreased mixing temperature. It was observed that the flow values of all the mixtures were between 2-4 mm, meeting the criteria of the agreement, except for the mixtures prepared with $18 \%$ Gilsonite modified bitumen at $20^{\circ} \mathrm{C}$ lower than the mixing temperature. It was determined that the mixtures prepared with pure binders and $18 \%$ Gilsonite had the lowest flow value at the mixing temperature while the highest flow value was observed in mixtures prepared at $20^{\circ} \mathrm{C}$ lower than the mixing temperature. It was also seen that there was a $12.8 \%$ difference between the highest and the lowest flow values of mixtures prepared with pure binders while the difference was $44.5 \%$ in mixtures prepared with $18 \%$ Gilsonite. In mixtures prepared with 5\% SBS, the lowest flow value was observed in the mixture prepared at the mixing temperature while the highest flow value was observed in the mixture prepared at $15^{\circ} \mathrm{C}$ lower than the mixing temperature. The difference between the highest and the lowest flow values of mixtures prepared with 5\% SBS were $19.5 \%$.

Flow values of HMA wearing courses should be between 2-4 mm according to Technical Specifications of the Turkish General Directorate of Highways. As seen in Figure 3, except mixtures prepared with $18 \%$ Gilsonite modified bitumen at $20^{\circ} \mathrm{C}$ lower than the mixing temperature, all mixtures met the specifications' requirements.

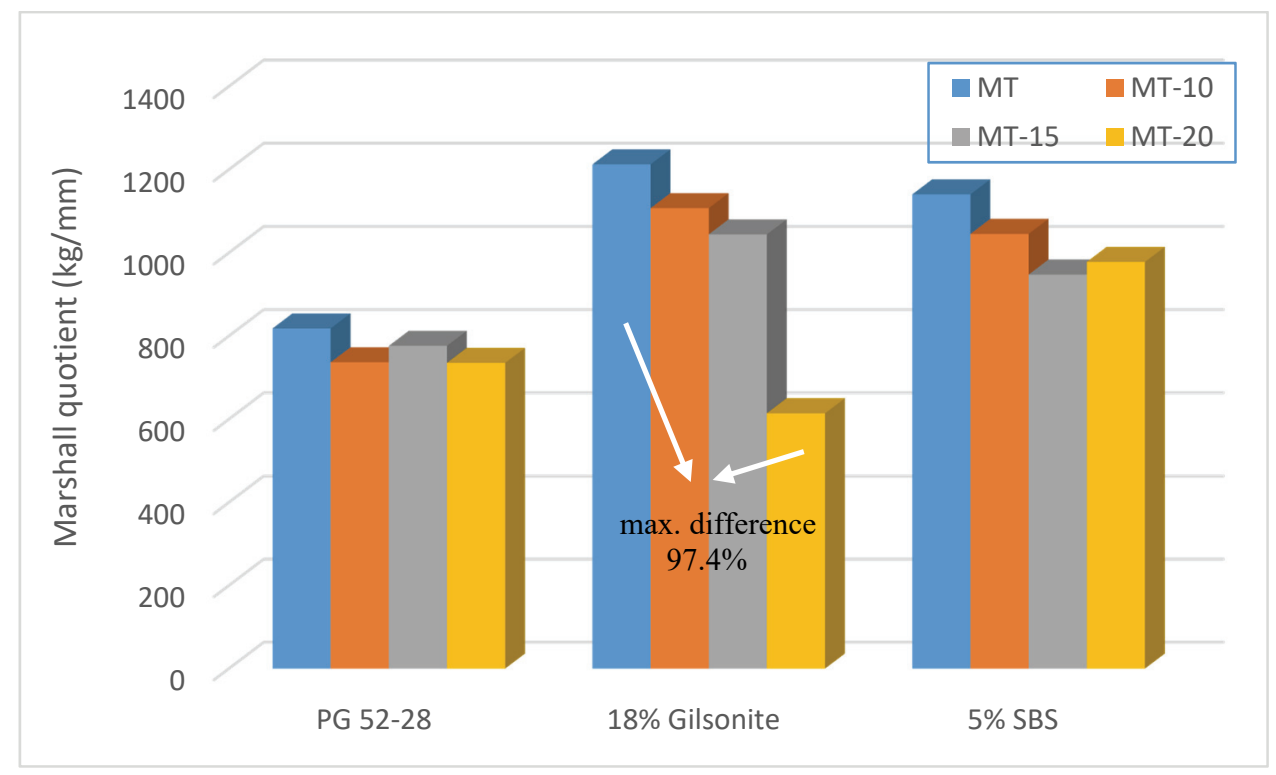

Figure 4 - MQ values of mixtures.

Marshall Quotient (MQ) value, which is the indicator of resistance to permanent deformation in HMAs, was determined by proportioning the stability values with flow values [31]. As it can be seen in Figure 4, with decreased mixing temperature, MQ values were generally decreased. It was maintained that the highest MQ values, thereby the highest resistance to permanent deformation, were obtained from mixtures prepared at the mixing temperature. The lowest MQ value was obtained from the mixtures prepared with pure binder and $18 \%$ 
Gilsonite modified binders at $20^{\circ} \mathrm{C}$ lower than the mixing temperature and, for the mixtures prepared with 5\% SBS modified bitumen, the lowest value was observed at mixtures prepared at $15^{\circ} \mathrm{C}$ lower than the mixing temperature. The difference between the highest and the lowest MQ values for mixtures prepared with pure bitumen was $11.3 \%$, while the difference was $97.4 \%$ for the mixtures prepared with $18 \%$ Gilsonite and $20.4 \%$ for the mixtures prepared with 5\% SBS modified bitumen.

\subsection{Resistance to Moisture-Induced Damage}

In order to determine the resistance to moisture-induced damage in the study, the samples were prepared and subjected to tests according to AASHTO T 283 standard. For 6 samples for each type of binder and each mixing temperature, a total of 72 Superpave HMA samples were prepared. In order to determine the moisture damages of the samples more clearly, the samples were prepared at $7 \% \pm 0.5$ air voids. Then, the prepared samples were divided into two groups in a way that their specific weights are close to each other. After that, the first group was subjected to vacuuming in a way that their voids were filled with $70-80 \%$ water. Following this process, these samples were held at $-18^{\circ} \mathrm{C}$ temperature for 16 hours and then held at $60^{\circ} \mathrm{C}$ water for 24 hours. While it was suggested to apply 1 cycle in the normal testing procedure, 5 freezing and thawing periods were applied in this study in order to determine the effects of mixing temperatures on the resistance to moisture-induced damage of HMAs. After the 5th period, the samples were kept in $25^{\circ} \mathrm{C}$ water for 2 hours and were cracked at the diametrical direction by applying a $50.8 \mathrm{~mm} / \mathrm{min}$ loading rate. The second group of samples was kept in $25^{\circ} \mathrm{C}$ water for 2 hours and the samples were cracked by applying a 50.8 $\mathrm{mm} / \mathrm{min}$ loading rate. Based on the maximum level of load at failure, the indirect tensile strength (ITS) in $\mathrm{kPa}$ is calculated by the following equation:

$\mathrm{ITS}=2 * \mathrm{~F} / \pi * \mathrm{~L} * \mathrm{D}$

where $\mathrm{F}$ is the peak value of the applied vertical load $(\mathrm{kN})$; $\mathrm{L}$ is the mean thickness of the test specimen $(\mathrm{m})$; and $\mathrm{D}$ is the specimen diameter $(\mathrm{m})$. In the study, the unconditioned samples were labeled as ITS $\mathrm{S}_{\text {uncond, }}$ while the conditioned samples were labeled as ITS $_{\text {cond. }}$.

The tensile strength ratio (TSR) value, which is an indicator of the resistance of the mixtures against moisture-induced damage, was determined as per the equation below:

TSR $=100 *\left(\right.$ ITS $_{\text {cond. }} /$ ITS $\left._{\text {uncond. }}\right)$

where ITS $_{\text {cond }}$ is the indirect tensile strength of the conditioned specimens and ITS $_{\text {uncond }}$ denotes the indirect tensile strength of the unconditioned specimens. The ITS $_{\text {uncond values of }}$ the samples were presented in Figure 5 while the ITS $_{\text {cond }}$ values were presented in Figure 6 and TSR values were presented in Figure 7.

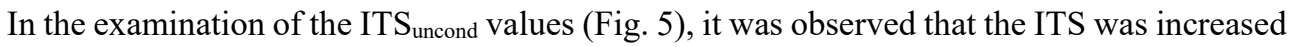
significantly with additive usage. With decreased mixing temperature in pure mixture, a consistent reduction in ITS values was observed. In mixtures prepared with $18 \%$ Gilsonite and 5\% SBS modified bitumen, with decreased mixing temperature, a consistent change was not observed in ITS values. In the pure mixture, the highest ITS value was observed in the 
mixture prepared at the mixing temperature while the lowest value was observed at $20^{\circ} \mathrm{C}$ lower than the mixing temperature. It was determined that the difference between the highest and the lowest ITS value was $20.1 \%$. In mixtures prepared with $18 \%$ Gilsonite modified bitumen, the highest value was observed at mixture prepared at $15^{\circ} \mathrm{C}$ lower than the mixing temperature while the lowest value was observed at the mixture prepared with at $10^{\circ} \mathrm{C}$ lower than the mixing temperature. For the mixtures prepared with $18 \%$ Gilsonite modified bitumen, the difference between the highest and the lowest ITS values was $6.5 \%$. While the values in mixtures prepared with 5\% SBS were rather close to each other, the highest value was observed in mixtures prepared at $10^{\circ} \mathrm{C}$ lower than the mixing temperature while the lowest value was observed at mixtures prepared at $20^{\circ} \mathrm{C}$ lower than the mixing temperature. The difference between the highest and the lowest ITS values was only $2.3 \%$.

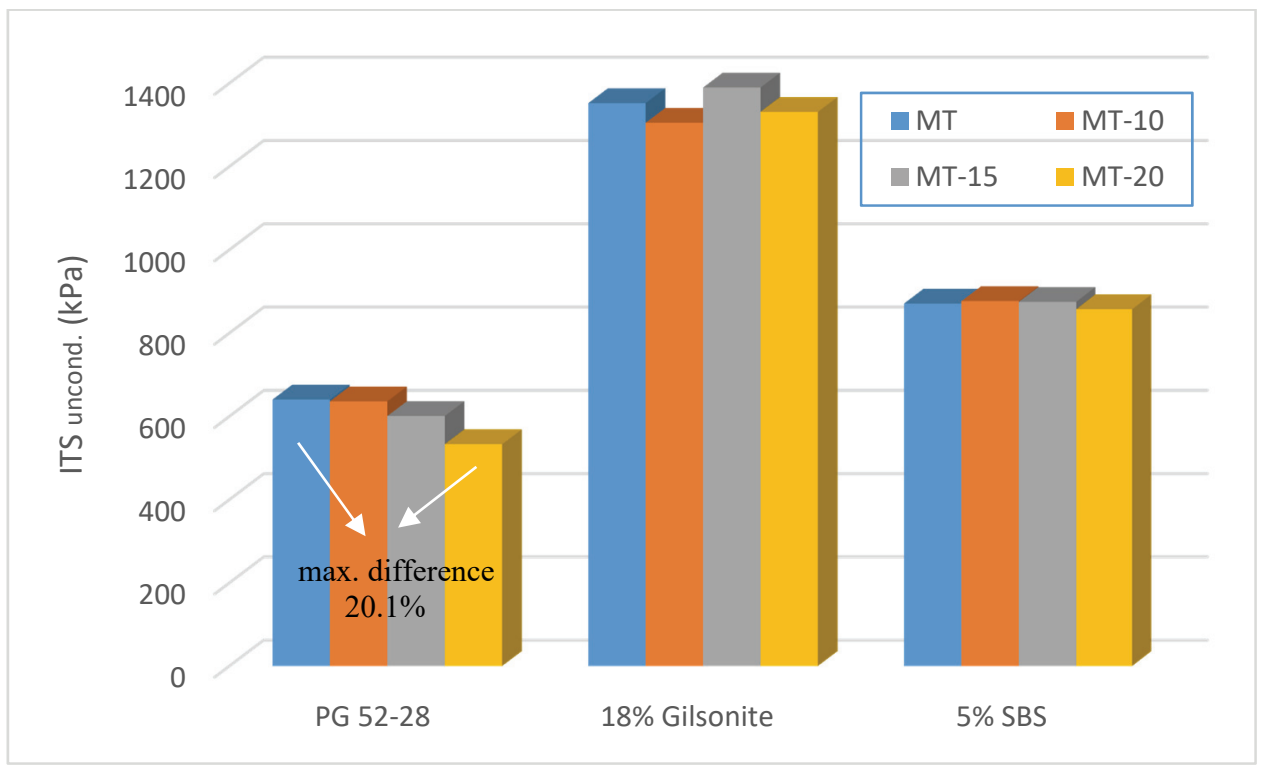

Figure 5 - ITS values of unconditioned mixtures.

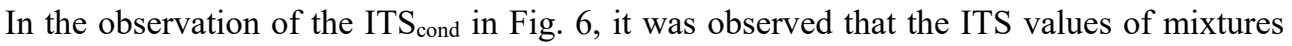
prepared with additives were higher compared to pure mixtures. Following the conditioning, while the ITS values of HMAs prepared with 5\% SBS modified bitumen decreased consistently with decreasing mixing temperature, the ITS values of mixtures prepared with other binders (pure and 18\% Gilsonite modified bitumen) did not demonstrate a consistent change with decreased mixing temperatures.

In mixtures prepared with pure binders, the highest value following the conditioning was observed in the mixtures prepared at $10^{\circ} \mathrm{C}$ lower than the mixing temperature while the lowest value was observed in mixtures prepared at $15^{\circ} \mathrm{C}$ lower than the mixing temperature. The difference between the ITS values of mixtures prepared with pure binders following the conditioning was $24.1 \%$. In mixtures prepared with $18 \%$ Gilsonite, following the conditioning, the highest ITS value was observed in mixtures prepared at $15^{\circ} \mathrm{C}$ lower than 
the mixing temperature while the lowest ITS value was observed in mixtures prepared at $10^{\circ} \mathrm{C}$ lower than the mixing temperature and the difference between the highest and the lowest ITS value was determined to be $22.7 \%$. In mixtures prepared with 5\% SBS modified bitumen, following the conditioning, the highest ITS value was observed in mixtures prepared at the mixing temperature and the lowest ITS value was observed in mixtures prepared at $20^{\circ} \mathrm{C}$ lower than the mixing temperature while the difference between the highest and the lowest ITS value was $7.0 \%$.

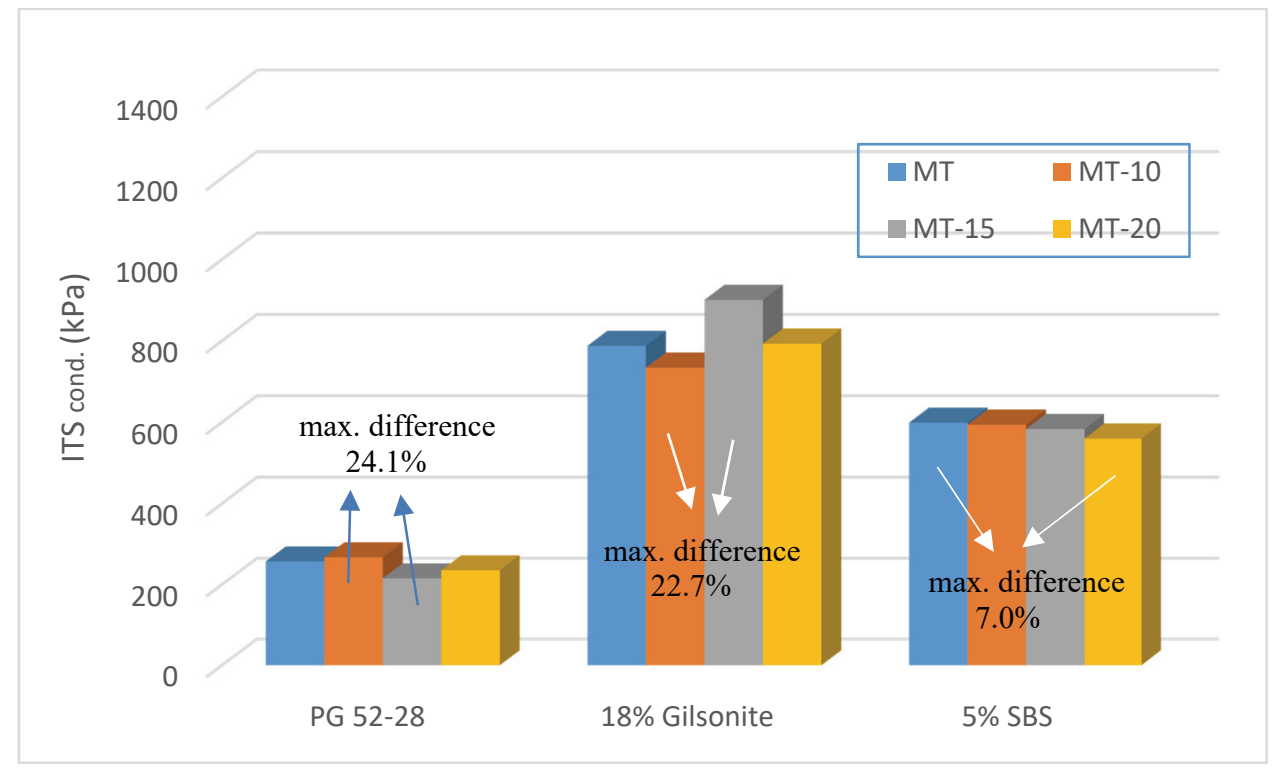

Figure 6 - ITS values of conditioned mixtures.

In the examination of the tensile strength ratio values in Fig. 7, it was determined that none of the mixtures met the criteria of Superpave specification limit (min. 80\%) due to conditioning for 5 successive times. However, the fact that even the worst TSR value was around $40 \%$ following the 5th freezing and thawing cycle supported the idea that all the mixtures would meet the criteria of the agreement.

In the evaluation of the mixtures, it was observed that the lowest TSR value was of pure mixture while the highest TSR value was of the mixtures prepared with 5\% SBS. The TSR value was observed to increase with additive usage. It was determined that SBS is more effective compared to Gilsonite in terms of resistance to moisture-induced damage.

In mixtures prepared with 5\% SBS modified binder, with decreased mixing temperature, TSR values were consistently decreased while it was observed that these values did not consistently change in mixtures prepared with other two binders. In mixtures prepared with pure binders, the lowest TSR value was observed in mixtures prepared at $15^{\circ} \mathrm{C}$ lower than the mixing temperature while the highest value was observed that mixtures prepared at $20^{\circ} \mathrm{C}$ lower than the mixing temperature and the difference between the highest and the lowest values were $23.0 \%$. In mixtures prepared with $18 \%$ Gilsonite modified binders, the highest 
TSR rate was observed in mixtures prepared at $15^{\circ} \mathrm{C}$ lower than the mixing temperature while the lowest rate was observed in mixtures prepared at $10^{\circ} \mathrm{C}$ lower than the mixing temperature and the difference between the highest and the lowest rate was $15.2 \%$. In the mixtures prepared with $5 \%$ modified binder, the highest tensile strength ratio was observed in mixtures prepared at the mixing temperature while the lowest rate was observed in mixtures prepared at $20^{\circ} \mathrm{C}$ lower than the mixing temperature and the difference between the highest and the lowest temperature was $5.3 \%$.

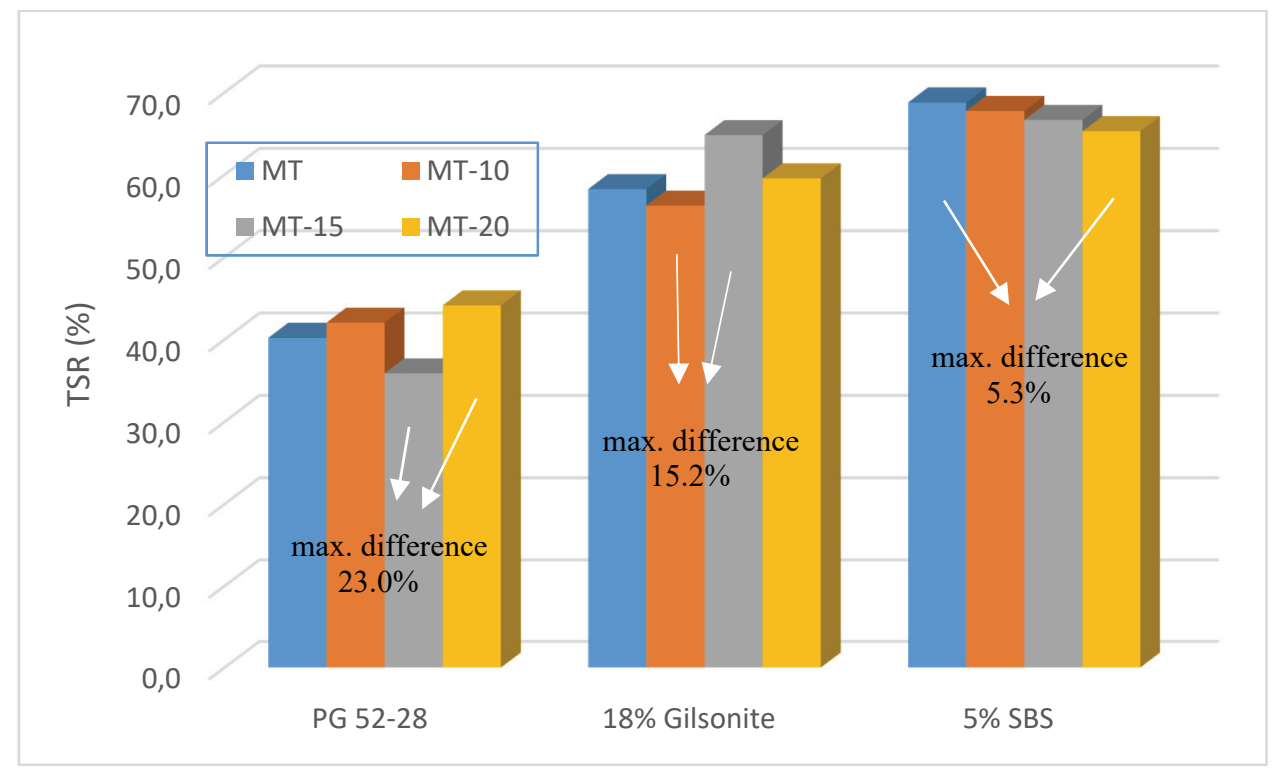

Figure 7 - TSR values of pure and modified binder included mixtures.

\subsection{Indirect Tensile Fatigue Test Results}

Indirect tensile fatigue tests were conducted on mixtures prepared with pure binders, $18 \%$ Gilsonite and $5 \%$ SBS modified bitumen at mixing temperatures of $10^{\circ} \mathrm{C}, 15^{\circ} \mathrm{C}$ and $20^{\circ} \mathrm{C}$ lower than the mixing temperature. The indirect tensile fatigue tests were performed in a controlled stress mode according to BS DD ABF standard [32]. 3 samples of each type of mixture, a total of 36 samples, were prepared for this test. The prepared samples were conditioned at $40^{\circ} \mathrm{C}$ for 3 hours. Then, repeated loading was applied by using Universal Test Machine (UTM). Because the main aim of the study is to investigate the effect of mixing temperatures on the performances of HMAs, fatigue tests at various stresses were conducted on each type of binder. In mixtures prepared with pure binders, the fatigue tests were conducted at $200 \mathrm{kPa}$ stress level, in mixtures prepared with $18 \%$ Gilsonite modified bitumen, at $350 \mathrm{kPa}$ stress level and in mixtures prepared with pure binders, at $250 \mathrm{kPa}$ stress level.

Indirect tensile fatigue tests were continued until the sample failed. Thus, the deformation values in the maximum load cycle number and maximum load cycle number were obtained 
via the software. As a result of the stress-controlled fatigue tests, the representative load repetition number-deformation level graph was plotted, see Fig. 8.

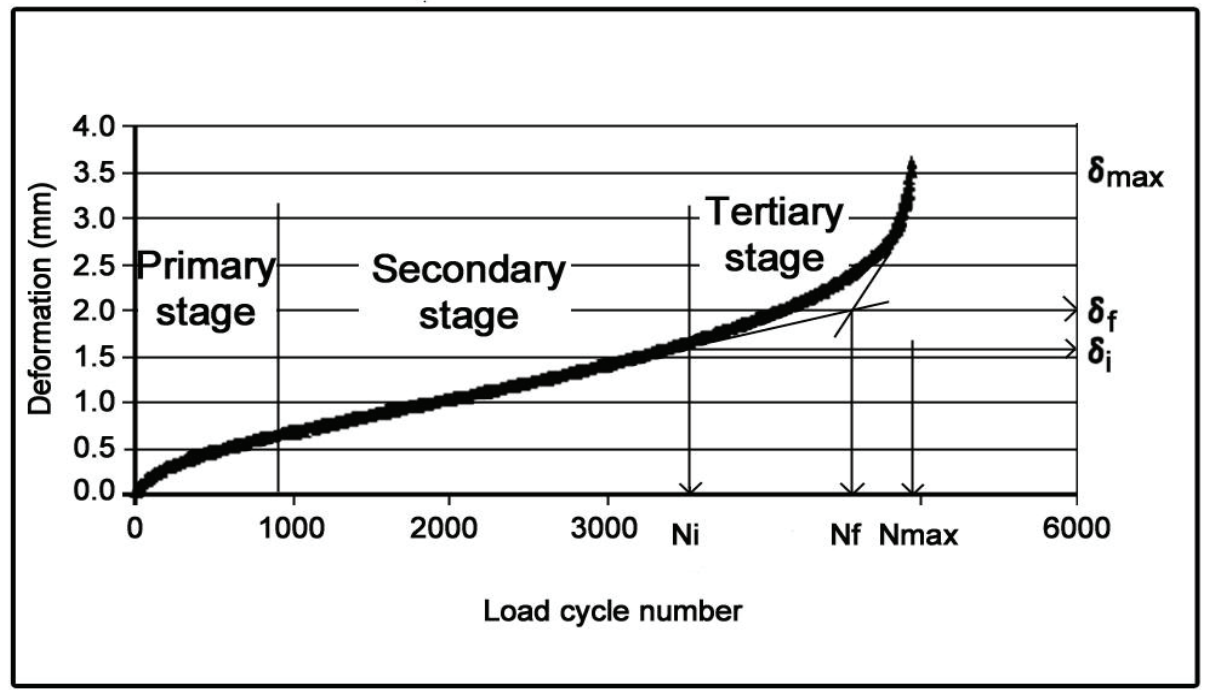

Figure 8 - A representative deformation-load repetition number relationship.

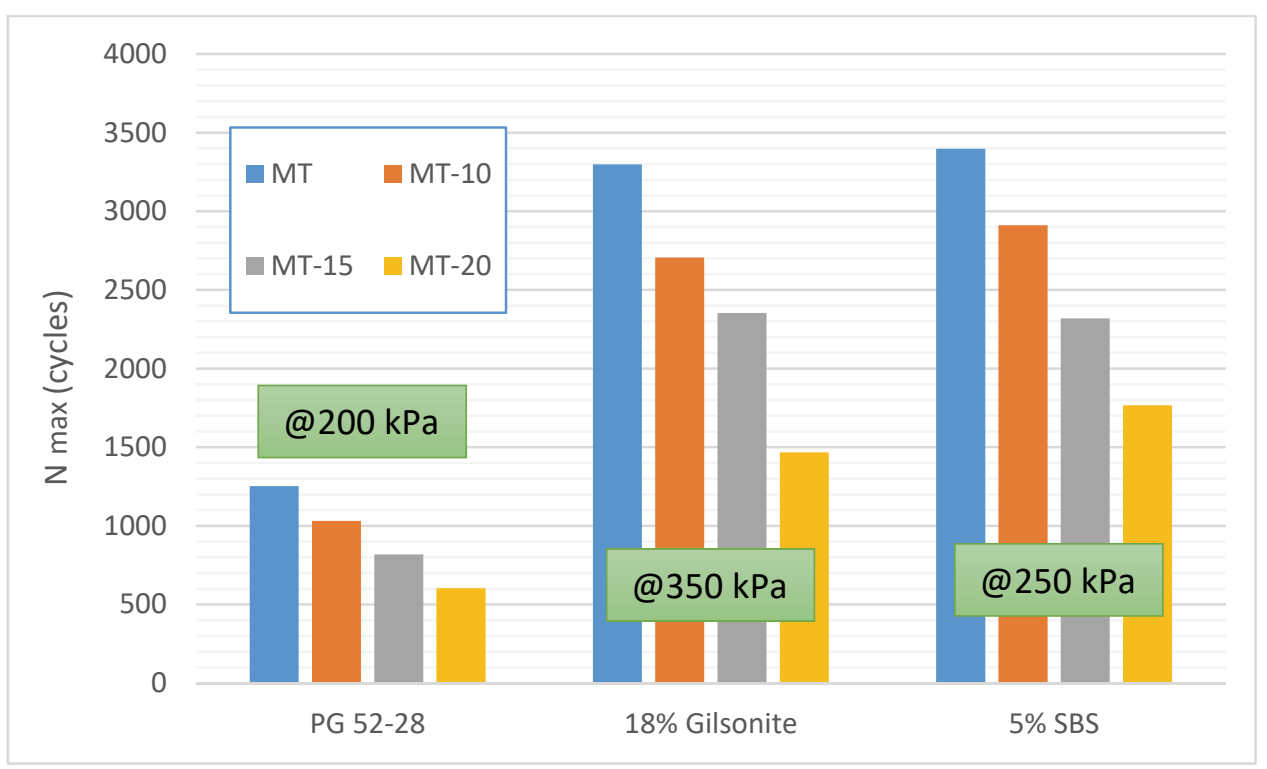

Figure 9 - The variation of $N_{\max }$ values of mixtures with the stress level and modifier type. 


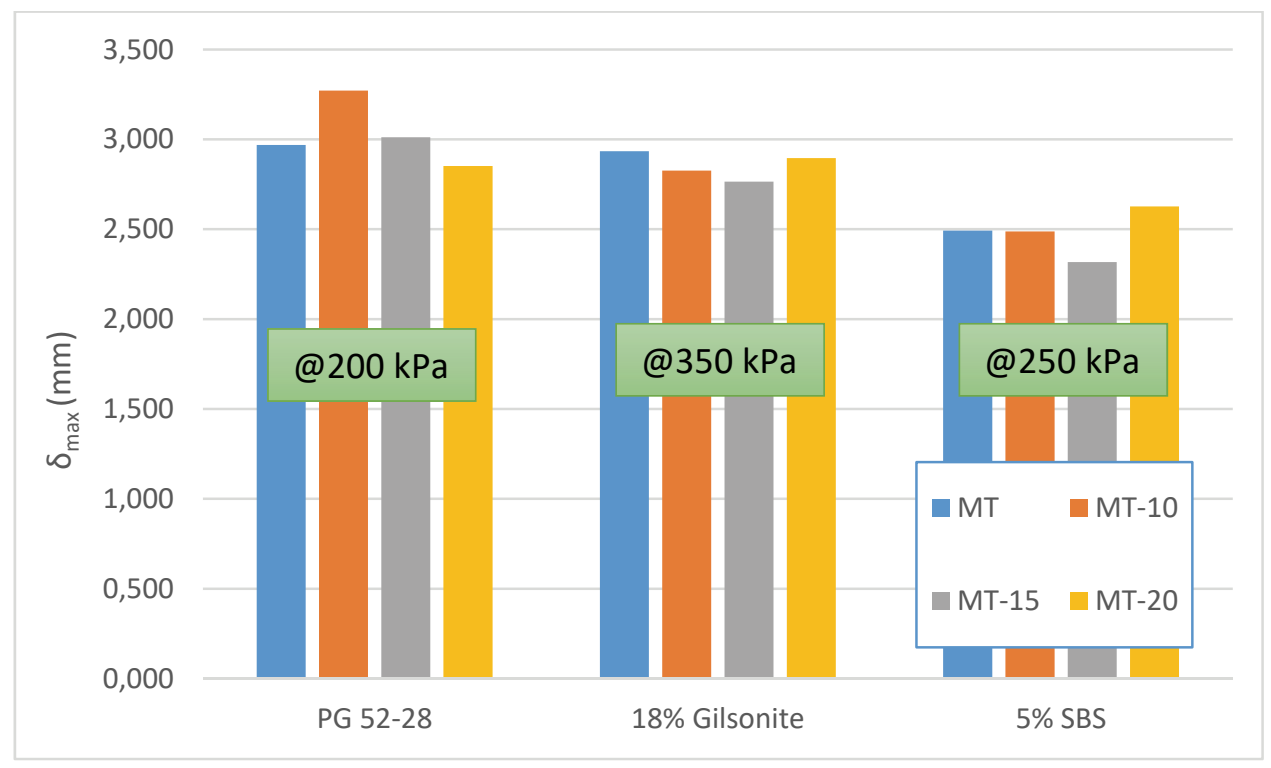

Figure 10 - The variation of $\delta_{\max }$ values of mixtures with the stress level and modifier type.

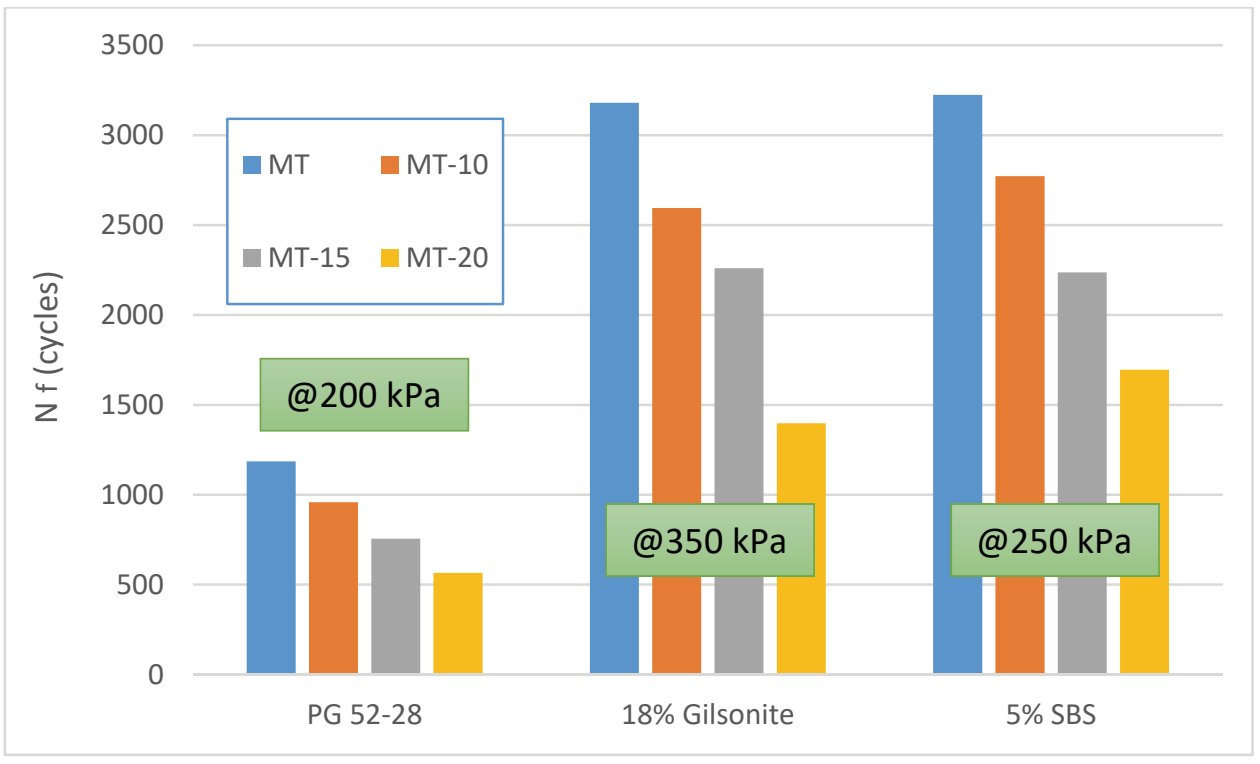

Figure $11-N_{f}$ values of mixtures. 


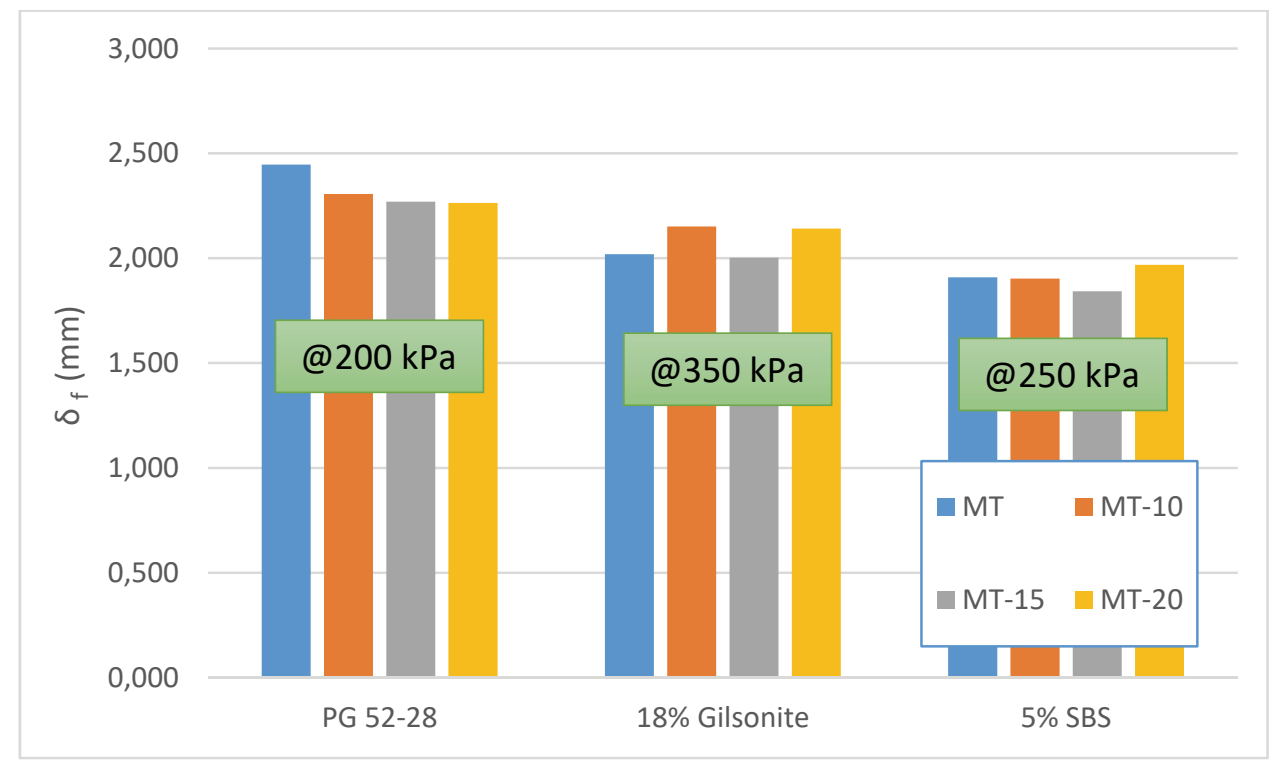

Figure $12-\delta_{f}$ values of mixtures.

Then, the results of the tests were transferred to Microsoft Excel and the fatigue lives of mixtures were determined by the junction points of 2 nd and 3rd zones [33]. Additionally, maximum load cycle numbers (Nmax) of mixtures were presented in Figure 9 and the deformation values at maximum load cycle number $(\delta \mathrm{max})$ were presented in Figure 10 while the fatigue lives (Nf) were provided in Figure 11, the deformation values at fatigue lives ( $\delta \mathrm{f}$ ) were presented in Figure 12.

In the observation of the maximum load cycle numbers in Figure 9, even though the mixtures prepared with modified bitumen were subjected to higher stresses, it was determined that the maximum load cycle numbers were higher in mixtures prepared with modified bitumen. In the comparison of the type of additive, it was observed that even though mixtures prepared with $18 \%$ Gilsonite were subjected to higher stresses, they had similar maximum load cycle number with mixtures prepared with 5\% SBS modified bitumen. Thus, the best results of these fatigue tests were obtained from mixtures prepared with $18 \%$ Gilsonite modified bitumen. It was also observed that in all of the binders, with decreased mixing temperature, the maximum load cycle number consistently decreased.

In mixtures prepared with pure binder at $10^{\circ} \mathrm{C}$ lower than the mixing temperature, the maximum load cycle number was decreased by $17.7 \%$ while at $15^{\circ} \mathrm{C}$ lower than the mixing temperature, it was $34.7 \%$ and at $20^{\circ} \mathrm{C}$ lower than the mixing temperature, it was decreased by $51.9 \%$. In mixtures prepared with $18 \%$ Gilsonite modified binder, the maximum load cycle number decreased by $18.0 \% ; 28.7 \%$ and $55.5 \%$ at $10^{\circ} \mathrm{C}, 15^{\circ} \mathrm{C}$ and $20^{\circ} \mathrm{C}$ lower than the mixing temperature, respectively. In mixtures prepared with $5 \%$ SBS modified binder, the maximum load cycle number decreased by $14.3 \% ; 31.8 \%$ and $48.0 \%$ at $10^{\circ} \mathrm{C}, 15^{\circ} \mathrm{C}$ and $20^{\circ} \mathrm{C}$ lower than the mixing temperature, respectively. According to the obtained results, it was 
determined that at $10^{\circ} \mathrm{C}$ and $20^{\circ} \mathrm{C}$ lower than the mixing temperature, the highest decrease was in mixtures prepared with $18 \%$ Gilsonite and at $15^{\circ} \mathrm{C}$ lower than the mixing temperature, the highest decrease was in mixtures prepared with pure bitumen. Especially at $20^{\circ} \mathrm{C}$ lower than the mixing temperature, the fact that the maximum load cycle number was decreased by approximately $50 \%$ demonstrated the significance of the mixing temperature in conditions with repeated loads.

In the observation of the deformation values in the maximum load cycle number of the mixtures (Fig. 10), it was determined that the highest deformation value in pure binder was in mixtures prepared at $10^{\circ} \mathrm{C}$ lower than the mixing temperature while the lowest deformation value was in mixtures prepared at $20^{\circ} \mathrm{C}$ lower than the mixing temperature. In the observation of mixtures prepared with $18 \%$ Gilsonite and 5\% SBS, the lowest deformation value was in mixtures prepared at $15^{\circ} \mathrm{C}$ lower than the mixing temperature. These results indicated that the mixtures would have more brittle fractures in a situation where the mixture prepared with pure binder was prepared at $20^{\circ} \mathrm{C}$ lower than the mixing temperature and the mixtures prepared with $18 \%$ Gilsonite and $5 \%$ SBS modified bitumen prepared at $15^{\circ} \mathrm{C}$ lower than the mixing temperature.

In the observation of the fatigue lives of the mixture, it was determined that the changes were similar to those in the maximum load cycle number (Fig. 11). In mixtures prepared with pure binder, when the mixing temperature is $10^{\circ} \mathrm{C}$ lower than the mixing temperature, the number of fatigue life load cycle was decreased by $19.2 \%$ while at $15^{\circ} \mathrm{C}$ lower than the mixing temperature, it was decreased by $36.3 \%$ and $20^{\circ} \mathrm{C}$ lower than the mixing temperature, it was decreased by $52.3 \%$. In mixtures prepared with $18 \%$ Gilsonite modified bitumen, with $10^{\circ} \mathrm{C}$, $15^{\circ} \mathrm{C}$ and $20^{\circ} \mathrm{C}$ lower than the mixing temperature, the number of fatigue life load cycle were decreased by $18.4 \% ; 28.9 \%$ and $56.0 \%$, respectively. In mixtures prepared with $5 \%$ SBS modified bitumen, with $10^{\circ} \mathrm{C}, 15^{\circ} \mathrm{C}$ and $20^{\circ} \mathrm{C}$ lower than the mixing temperature, the number of fatigue life load cycle were decreased by $14.0 \% ; 30.6 \%$ and $47.4 \%$, respectively. According to the obtained results, it was determined that at $10^{\circ} \mathrm{C}$ and $15^{\circ} \mathrm{C}$ lower than the mixing temperature, the mixtures prepared with pure bitumen had the highest decrease in the number of fatigue life load repeated while at $20^{\circ} \mathrm{C}$ lower than the mixing temperature, the highest decrease was in mixtures prepared with $18 \%$ Gilsonite modified bitumen.

In the observation of the deformation values in fatigue lives of the mixtures (Fig. 12), it was observed that the lowest deformation value in mixtures prepared with pure binders was at $20^{\circ} \mathrm{C}$ lower than the mixing temperature while in mixtures prepared with $18 \%$ Gilsonite and $5 \%$ SBS modified bitumen, the lowest deformation value was in mixtures prepared at $15^{\circ} \mathrm{C}$ lower than the mixing temperature. This situation indicated that these mixtures would cause more brittle fractions.

\section{SUMMARY AND CONCLUSIONS}

In this study, three different types of binders (pure bitumen, $18 \%$ Gilsonite and 5\% SBS modified bitumen) and limestone type crushed aggregate were used at 4 different mixing temperatures (the mixing temperature, $10^{\circ} \mathrm{C}, 15^{\circ} \mathrm{C}$ and $20^{\circ} \mathrm{C}$ lower than the mixing temperature) for the preparation of mixture samples. The values of mixing temperatures were determined by using the viscosity values (the values corresponding to $170 \mathrm{cP}$ ). The mixture samples were prepared by using Superpave gyratory compactor. By conducting Marshall 
Stability and flow, resistance to moisture-induced damage and indirect tensile fatigue tests on the mixture samples, the effects of mixing temperatures on the performance of HMAs were investigated.

As a result of the Marshall Stability and flow tests, it was determined that the stability values were increased as a result of additive usage. Additionally, with declined mixing temperatures, the stability and MQ values of the mixtures were generally decreased and the flow rates increased. It was also determined that the mixture prepared with $18 \%$ Gilsonite was the one affected most by the changes in the mixing temperature.

In the comparison of the moisture-induced damage tests, with additive use both before and after the conditioning, it was determined that tensile strength values were increased. Gilsonite was more effective on tensile strength values compared to SBS. However, SBS was more effective in tensile strength ratio, which is an indicator for resistance to moisture-induced damage, compared to Gilsonite. In the evaluation of the effects of mixing temperature on ITS and TSR, while there was no consistent change, it can be concluded that with decreasing mixing temperatures, tensile strength values were decreased in general.

In the evaluation of the indirect tensile fatigue tests, it was observed that the fatigue lives of mixtures were increased with additive use. The most effective additive on indirect tensile fatigue test results was Gilsonite. With decreased mixing temperature, fatigue life values of all of the mixtures were decreased. This situation indicated that the decrease in the mixing temperature influenced the fatigue performance of the mixture negatively. In the evaluation of the deformation values, it can be concluded that with decreased mixing temperature, there was no consistent change.

When all the tests results were taken into consideration, it was concluded that additive use had positive effect on the performances of HMAs positively. Additionally, in cases where the mixing temperature is lower than what it is supposed to be, the performances of the mixtures would be affected negatively and especially the fatigue life would be affected substantially in a negative way. It was also determined that, in the evaluation of the effects of mixing temperature, dynamic test methods (indirect tensile fatigue) had more precise results compared to static test methods (Marshall stability and flow, indirect tensile strength). It can also be mentioned that in the HMAs produced for the investigation, attention paid to the mixing temperature of bitumen and aggregate in the plant is crucial for the performance of the mixture. In this study, only one type of aggregate and bitumen were used. Studies with materials obtained from different sources would further augment the validity of the results. Additionally, the effects on performance should be investigated in the event that when HMAs are prepared at higher temperatures than the indicated mixing temperature.

\section{Symbols}

$\begin{array}{ll}\mathrm{G}^{*} & \text { : Complex shear modulus } \\ \text { HMA } & \text { : Hot mix asphalt } \\ \text { ITS } & \text { : Indirect tensile strength } \\ \text { MT } & \text { : Mixing temperature }\end{array}$




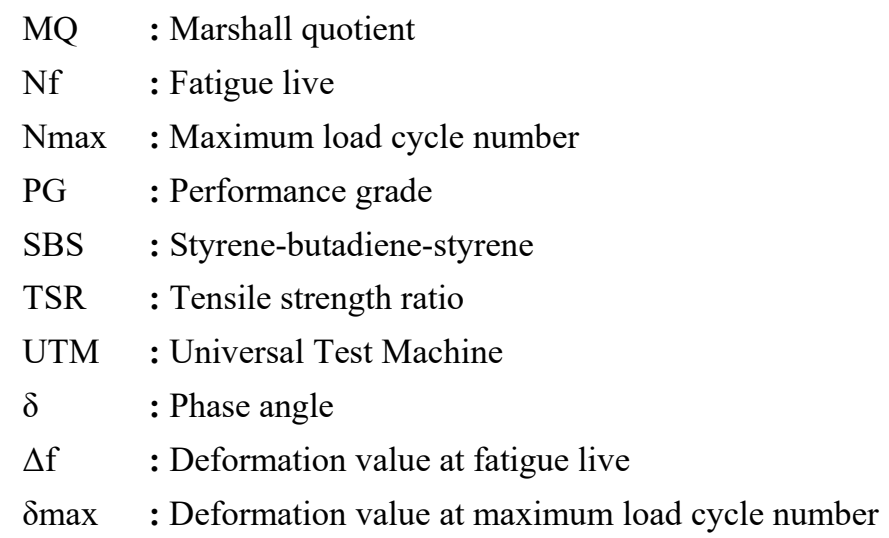

\section{References}

[1] Kök, B.V., Yilmaz, M., Kuloglu, N., Asfaltitin Bitüm ve Bitümlü Sıcak Karışımların Mekanik Özelliklerine Etkisi, İMO Teknik Dergi, 5813-5826, 2012.

[2] Benhood, A., Olek, J., Rheological properties of asphalt binders modified with styrenebutadiene-styrene (SBS), ground tire rubber (GTR), or polyphosphoric acid (PPA), Construction and Building Materials, 151: 464-478, 2017.

[3] Whiteoak, D., Shell Bitumen Handbook, Shell Bitumen UK, Riversdell Hause, 1990.

[4] Zhu, J., Birgisson, B., Kiringos, N., Polymer modification of bitumen: advances and challenges, European Polymer Journal, 54: 18-38, 2014.

[5] Ahmedzade, P., Alataş, T., Geçkil, T., Asfalt Betonunda Siyah Karbonun Filler Olarak Kullanımı, İMO Teknik Dergi, 4493-4507, 2008.

[6] Kök, B.V., Yılmaz, M., Erkuş, Y., Effect of graphite on mechanical properties of stone mastic asphalt pavement, Journal of Civil Engineering and Management 23 (8): 10131020, 2017.

[7] Topal, A., Evaluation of the properties and microstructure of plastomeric polymer modified bitumens, Fuel Processing Technology, 91 (1): 45-51, 2010.

[8] Nejad, F.M., Azarhoosh, A.R., Hamedi, G.H., Azarhoosh, M.J., Characterization of permanent deformation resistance of precipitated calcium carbonate modified asphalt mixture, Journal of Civil Engineering and Management, 21 (5): 615-622, 2015.

[9] Şengöz, B., Işıkyakar, G., Analysis of styrene-butadiene-styrene polymer modified bitumen using fluorescent microscopy and conventional test methods, Journal of Hazardous Materials, 150: 424-432, 2008.

[10] Kumar, K., Singh, A., Maity, S.K., Srivastava, M., Sahai, M., Singh, R.K., Garg, M.O., Rheological studies of performance grade bitumens prepared by blending elastomeric SBS (styrene butadiene styrene) co-polymer in base bitumens, Journal of Industrial and Engineering Chemistry, 44: 112-117, 2016. 
[11] Isacsson, U., Lu, X., Testing and appraisal of polymer modified road bitumens: state of the art, Materials and Structures, 28: 139-159, 1995.

[12] Cavaliere, M.G., Diani, E., Dia, M.D., Dynamic mechanical characterization of binder and asphalt concrete, Proceedings of the Euroasphalt and Eurobitume Congress, 7-10 May, Strasbourg, France, 1996.

[13] Brown, S.F., Rowlett, R.D., Boucher, J.L., Asphalt modification, Proceedings of the conference The United States strategic highway research program, 29-31 October, London, England, 181-203, 1990.

[14] Bahia, H.U., Hanson, D.I., Zeng, M., Zhai, H., Khatri M.A., Anderson, R.M., Characterization of modified asphalt binders in Superpave mix design, Project No. 910, Washington, DC: Transportation Research Board, 2001.

[15] Davis N., Tooman, C.E., New laboratory tests evaluate the effectiveness of Gilsonite resin as a borehole stabilizer, SPE Drilling Engineering, 4(1): 47-56, 1989.

[16] Ameri, M., Mansourian, A., Ashani, S.S., Yadollahi, G., Technical study on the Iranian Gilsonite as an additive for modification of asphalt binders used in pavement construction, Construction and Building Materials, 25: 1379-1387, 2011.

[17] Bardesi, A., Brule, B., Corte, J.F., Diani, E., Gerritsen, A., Lefevre, G., Watkins, S., Use of modified bituminous binders, special bitumens and bitumens with additives in pavement applications, Technical Committee Flexible Roads (C8) World Road Association (PIARC), Paris, France, 1999.

[18] Widyatmoko, I., Elliott, R., Characteristics of elastomeric and plastomeric binders in contact with natural asphalts, Construction and Building Materials, 22: 239-249, 2008.

[19] Babagoli, R., Hasaninia, M., Namazi, N.M., Laboratory evaluation of the effect of Gilsonite on the performance of stone matrix asphalt mixtures, Road Materials and Pavement Design, 16 (4): 889-906, 2015.

[20] Jahanian, H.R., Shafabakhsh, G.H., Divandari, H., Performance evaluation of hot mix asphalt (HMA) containing bitumen modified with Gilsonite, Construction and Building Materials, 131: 156-164, 2017.

[21] Anderson, D.A., Maurer, D., Ramirez, T., Christensen, D.W., Marasteanu, M.O., Mehta, Y., Field performance of modified asphalt binders evaluated with Superpave test methods, Transportation Research Record, 1661: 60-68, 1999.

[22] Huang, B., Li, G., Shu, X., Investigation into three-layered HMA mixtures, Composites, 37: 679-690, 2006.

[23] Quintana, H.A.R., Noguera, J.A.H., Bonells, C.F.U., Behavior of Gilsonite-modified hot mix asphalt by wet and dry processes, ASCE Journal of Materials in Civil Engineering, 28 (2): 04015114, 10.1061/(ASCE)MT.1943-5533.0001339, 2015.

[24] Yilmaz, M., Yalcin, E., The effects of using different bitumen modifiers and hydrated lime together on the properties of hot mix asphalts, Road Materials and Pavement Design, 17 (2): 499-511, 2016. 
[25] Yilmaz, M., Çeloğlu, M.E., Effects of SBS and different natural asphalts on the properties of bituminous binders and mixtures, Construction and Building Materials, 44: 533-540, 2013.

[26] Suo, Z., Wong, W.G., Analysis of fatigue crack growth behavior in asphalt concrete material in wearing course, Construction and Building Materials, 23: 462-468, 2009.

[27] Asphalt Institute, Superpave mix designs, Superpave series no: 2, (SP-2), Asphalt Institute, Lexington, KY, USA, 2003.

[28] Turkish Asphalt Contractors Association (ASMUD) technical datas, date of Access: 10.13.2018, http://www.asmud.org.tr/asfalt.php?sayfa=25.

[29] Yilmaz, M., Yamaç, Ö.E., Evaluation of Gilsonite and styrene-butadiene-styrene composite usage in bitumen modification on the mechanical properties of hot mix asphalts, ASCE Journal of Materials in Civil Engineering, 29(9): 10.1061/(ASCE) MT.1943-5533.0001938, 2017.

[30] Zaniewski, J.P., Pumphrey, M.E., Evaluation of performance graded asphalt binder equipment and testing protocol, Morgantown, WV: Asphalt Technology Program, Department of Civil and Environmental Engineering, 2004.

[31] Zoorob, S.E., Suparma, L.B., Laboratory design and investigation of the properties of continuously graded asphaltic concrete containing recycled plastics aggregate replacement (plastiphalt), Cement and Concrete Composites, 22(4): 233-242, 2000.

[32] BS DD ABF, Method for determination of the fatigue characteristics of bituminous mixtures using indirect tensile fatigue, Draft for Development, British Standards Institution, London, England, 1997.

[33] Aragao, F.T.S., Lee, J., Kim, Y.R., Karki, P., Material specific effects of hydrated lime on the properties and performance behaviour of asphalt mixtures and asphaltic pavements, Construction and Building Materials, 24 (4): 538-544, 2010. 
